\title{
Pengaruh Kompensasi Finansial dan Non Finansial Terhadap Efektivitas Pengelolaan SDN di Kabupaten Kutai Kartanegara Kalimantan Timur
}

\author{
Nur Agus Salim \\ Prodi Manajemen Pendidikan Universitas Mulawarman Samarinda \\ nuragussalim@uwgm.ac.id
}

\begin{abstract}
The purpose of this study was to determine the effect of financial and non-financial compensation on the effectiveness of school management. The research method used is quantitative approach. Data collection techniques used questionnaires and data analysis techniques using descriptive and inferential statistics. From result of hypothesis test that there is significant and positive influence between financial and non financial compensation to effectiveness of school management with result of test $F=148.582$ and t test $=12.189$ with significance value 0,000. The contribution of financial and non-financial compensation to effectiveness variable of school management is 0,347 which can be interpreted that 34,7\% variance of school management effectivity can be influenced by financial and non financial compensation variable and the rest is influenced by other variable not examined in this research. Based on these results it can be concluded that the better the financial and non-financial compensation then the better the effectiveness of primary schools in Kutai Kartanegara.
\end{abstract}

Keywords: Effectiveness of school management, Financial and non-financial compensation

\section{PENDAHULUAN}

Sekolah Dasar merupakan salah bentuk pendidikan dasar yang tertuang dalam Undang-Undang Republik Indonesia Nomor 20 Tahun 2003 tentang Sistem Pendidikan Nasional (UU Sisdiknas). Dalam pasal 17 menerangkan bahwa: (1) Pendidikan dasar merupakan jenjang pendidikan yang melandasi jenjang pendidikan menengah. (2) Pendidikan dasar berbentuk sekolah dasar (SD) dan madrasah ibtidaiyah (MI) atau bentuk lain yang sederajat serta sekolah menengah pertama (SMP) dan madrasah tsanawiyah (MTs), atau bentuk lain yang sederajat. (3) Ketentuan mengenai pendidikan dasar sebagaimana dimaksud pada ayat (1) dan (2) diatur lebih lanjut dengan peraturan pemerintah.

Sekolah Dasar merupakan salah satu jenjang pendidikan yang berlangsung selama 6 tahun dan merupakan jenjang pendidikan formal yang mempunyai peran besar bagi keberlangsungan proses pendidikan selanjutnya. Hal ini sesuai dengan Undangundang RI Nomor 20 Tahun 2003 pasal 17 ayat 1 yang menyebutkan bahwa " Pendidikan dasar merupakan jenjang pendidikan yang melandasi jenjang pendidikan menengah." Sehingga output dari sekolah dasar menentukan sekali terhadap perkembangan siswa pada pendidiakn lanjut yakni pendidkan menengah setingkat SMP atau MTs. Pada masa ini anak-anak akan diajarkan berbagai ilmu pengetahuan atau mata pelajaran yang relevan dengan tingkat usianya dan tentunya yang menunjang untuk kelanjutan pendidikanya ke jenjang yang lebih tinggi. Sekolah berlomba-lomba melaksanakan berbagai program sekolah agar dapat memperoleh prestasi sekolah yang baik. Untuk memperoleh prestasi sekolah yang baik diperlukan pengelolaan sekolah yang baik. Pengelolaan sekolah yang baik dibutuhkan suatu standar khusus agar terjadi pemerataan di tiap sekolah/madrasah. Standar Pengelolaan Pendidikan diatur dalam Peraturan Menteri Pendidikan Nasional No.19 tahun 2007. Peraturan Menteri tersebut terdapat hal-hal yang harus diperhatikan dalam pengelolaan pendidikan di antaranya, Perencanaan Program, Pelaksanaan Rencana Kerja, Pengawasan dan Evaluasi, Kepemimpinan sekolah/madrasah, Sistem Informasi Manajemen, dan Penilaian Khusus. Serta tertuang pula dalam Peraturan Pemerintah No. 19 Tahun 2005 tentang Standar Nasional Pendidikan Pasal 49 s/d 58 yang mengatur tentang standar pengelolaan pendidikan oleh satuan pendidikan yang berkaitan dengan perencanaan, pelaksanaan, dan pengawasan 
kegiatan pendidikan pada tingkat satuan pendidikan agar tercapai efisiensi dan efektivitas penyelenggaraan pendidikan. Karena pentingnya sekolah dasar dalam mempersiapkan anak bangsa yang berkualitas dari segi prestasi maun akhlak kedepan, maka penyelenggaraan sekolah dasar tidak dapat dilakukan tanpa adanya pengelolaan yang baik. Kualitas pendidikan dapat dilihat dari nilai tambah yang dihasilkan oleh lembaga pendidikan, baik produk dan jasa maupun pelayanan yang mampu bersaing di lapangan kerja yang ada dan yang diperlukan. Pendidikan yang dimaksud adalah pendidikan formal yang dilakukan melalui sekolah. Pengelolaan pendidikan dasar menjadi bagian penentu kemajuan tercapainya tujuan pendidikan dasar.

Upaya peningkatan yang dilakukan pemerintah dalam peningkatan mutu sekolah tertuang dalam UU No. 23 tahun 2014 tentang Pemerintahan Daerah tanggung jawab pendidikan setingkat SD/SMP berada dalam lingkup pemerintah kabupaten/kota sedangkan Pemerintah Provinsi bertanggung jawab atas pendidikan setingkat SMA/SMK dan Pemerintah Pusat bertanggung jawab atas pendidikan tinggi. Undang-undang ini mengamanatkan pemerintah daerah tingkat II agar dapat berkonsentrasi penuh dalam peningkatan mutu pendidikan dasar yang meliputi kewenangan-kewenangan menyangkut alokasi dana dari APBN dan APBD, tenaga pengajar, infrastruktur sekolah, pembangunan sekolah, dan siswa sedangkan pendidikan menengah akan dikelola oleh pemerintah daerah tingkat I. Dengan otonomi pengelolaan melalui manajemen berbasis sekolah sebagian besar keputusan pendidikan harus dibuat ditingkat sekolah. Otonomi pengelolaan ini mengikutsertakan peran stake holder atau yang berkepentingan terhadap pendidikan untuk ikut serta mempengaruhi keberhasilan sekolah. Esensi hubungan sekolah-masyarakat maupun dunia usaha dan industri adalah untuk meningkatkan keterlibatan, kepedulian, kepemilikan, dan dukungan dari masyarakat terutama dukungan moral dan finansial.

Otonomi atau kemandirian yang lebih besar kepada sekolah dan dapat mendorong pengambilan keputusan partisipatif yang melibatkan secara langsung semua warga sekolah sesuai standar mutu yang berkaitan dengan kebutuhan sarana prasarana, fasilitas sekolah, peningkatan kualitas kurikulum, dan pertumbuhan jabatan guru. Keputusan sekolah yang diambil harus melibatkan secara langsung semua warga sekolah, yaitu guru, siswa, kepala sekolah, karyawan, orang tua siswa dan masyarakat yang berhubungan dengan program sekolah. Desentralisasi sekolah disini akan memindahkan otoritas pengambilan keputusan manajemen ke setiap pemerintah tingkat lokal sehingga mereka lebih mandiri dan mampu menentukan arah pembangunan yang sesuai dengan kondisi tuntutan masyarakatnya. Salah satu implementasi dari disentralisasi pendidikan yaitu tentang penentuan kelulusan peserta didik ditentukan oleh Satuan Pendidikan.

Kenyataan di lapangan masih banyak ditemukan permasalahan dalam implementasi MBS di sekolah dasar adalah manajemen kurikulum, manajemen peserta didik, manajemen sarana dan prasarana, pembiayaan dan manajemen pendidik dan tenaga kependidikan. Melihat realita dan fakta tersebut maka perlu motivasi kuat bagi pengelola, pendidik dan tenaga kependidikan sekolah dasar untuk mengelola sekolah menjadi efektif untuk menjadikannya sebuah lembaga yang potensial. Kuncinya tentu saja pengelolaan sekolah yang efektif yang menjunjung pengabdian serta mengarah profesionalisme baik dalam pengadaan sarana, penerapan metode pembelajaran dan kurikulum serta rekruitmen tenaga pendidik dan kependidikan. Efektivitas sebagai orientasi kerja menyoroti empat hal, Yaitu : (a) sumber daya, dana, sarana dan prasarana yang dapat digunakan sudah ditentukan dan dibatasi, (b) jumlah dan mutu barang atau jasa yang harus dihasilkan telah ditentukan, (c) batas waktu untuk menghasilkan barang atau jasa tersebut sudah ditetapkan, (d) tata cara yang harus ditempuh untuk menyelesaikan tugas sudah dirumuskan.

Berdasarkan kenyataan tersebut di atas, perlu dilakukan upaya-upaya perbaikan, salah satunya adalah melakukan reorientasi penyelenggaraan pendidikan. Misalnya tidak diperlukannya lagi intervensi pemerintah pusat ke daerah atau ke sekolah. Hal ini dimaksudkan supaya otonomi sekolah untuk menentukan sendiri apa yang perlu dilakukan dalam kegiatan belajar mengajar dan mengelola sumber daya yang ada untuk berinovasi semakin meningkat. Sedangkan partisipasi masyarakat ditampakkan pada tingginya keterlibatan mereka sehingga setiap unsur dapat berperan dalam meningkatkan kualitas, efisiensi, dan pemerataan kesempatan, pendidikan dengan 
memodifikasi struktur pengambilan keputusan dari pemerintah pusat ke daerah dan seterusnya ke sekolah. Oleh karena itu penulis tertarik untuk melakukan penelitian mengenai pengaruh kompensasi finansial dan non finansial terhadap Efektivitas Pengelolaan Sekolah Dasar (SD) Negeri di Kabupaten Kutai Kartanegara Provinsi Kalimantan Timur.

\section{METODE PENELITIAN}

Penelitian ini dilakukan pada SD-SD Negeri yang tersebar pada 3 Kecamatan di Kabupaten Kutai Karetanegara Provinsi Kalimantan Timur yakni kecamatan Samboja, Muara Jawa dan kecamatan Sanga-sanga. Alasan memilih ketiga kecamatan ini adalah karena kecamatan Samboja, Muara Jawa dan Sanga-sanga merupakan kecamatan yang memiliki pendapatan asli daerah yang cukup besar dan jumlah sekolah serta tenaga pengajar yang banyak sehingga perlunya penelitian ini dilakukan guna mengetahui bagaimanakah pengelolaan sekolah dasarnya serta dikarenakan belum adanya penelitian yang dilakukan mengenai pengelolaan sekolah di ketiga kecamatan tersebut selama ini.

Penelitian dilaksanakan selama enam bulan, dimulai pada bulan Januari 2017 sampai dengan Juni 2017. Pada bulan Januari 2017 dilaksanakan pengurusan izin penelitian, ujicoba instrumen, kalibrasi, dan penyempurnaan instrumen. Pada bulan Februari 2017 s/d Juni 2017 dilaksanakan pengambilan data, analisis data, dan penulisan seminar hasil penelitian.

Dalam penelitian ini metode yang dipakai adalah metode penelitian kuantitatif.
Metode ini digunakan untuk mengetahui adanya pengaruh kemampuan manajerial kepala sekolah, kompensasi, manajemen konflik, dan pengambilan keputusan terhadap efektivitas pengelolaan sekolah pada sekolah dasar negeri di Kabupaten Kutai Kartanegara. Pertama-tama penulis akan mencari pengaruh kemampuan manajerial kepala sekolah terhadap efektivitas pengelolaan sekolah, kemudian pengaruh kompensasi terhadap efektivitas pengelolaan sekolah, pengaruh manajemen konflik terhadap efektifitas pengelolaan sekolah dan pengaruh pengambilan keputusan terhadap efektivitas pengelolaan sekolah serta mencari pengaruh secara bersama-sama antara kemampuan manajerial kepala sekolah, kompensasi , manajemen konflik dan pengambilan keputusan terhadap efektivitas pengelolaan sekolah dasar negeri di Kabupaten Kutai Kartanegara dengan memperoleh data menggunakan angket. Namun sebelum penulis mengambil data terlebih dahulu penulis akan melakukan uji coba instrumen untuk menguji validitas dan reabilitasnya. Setelah penganalisaan instrumen dilakukan kemudian dilakukan pengumpulan data dengan menggunakan instumen yang valid dari hasil uji validitas dan reabilitas tersebut.

Populasi dalam penelitian ini adalah pengajar pada SD-SD Negeri di Kecamatan Samboja, Muara Jawa dan Sanga-sanga. Jumlah populasinya adalah seluruh pengajar pada SD-SD Negeri yang tersebar di wilayah zona 5 Kabupaten Kutai Kartanegara Provinsi Kalimantan Timur dengan rincian sebagai berikut:

Tabel 1. Populasi Penelitian

\begin{tabular}{clcc}
\hline No & Kecamatan & $\begin{array}{c}\text { Jumlah } \\
\text { Sekolah }\end{array}$ & $\begin{array}{c}\text { Jumlah } \\
\text { Pendidik }\end{array}$ \\
\hline 1 & Samboja & 40 & 449 \\
\hline 2 & Muara Jawa & 18 & 298 \\
\hline 3 & Sanga-sanga & 15 & 208 \\
\hline & Total & 73 & 955 \\
\hline
\end{tabular}

Teknik pemilihan sampel yang digunakan adalah sampel yang diambil kurang proporsional karena responden dengan pendidikan D3, S1 dan S2 tidak seimbang sehingga untuk responden dengan pendidikan D3 dan S2 akan diambil seluruhnya karena jumlahnya sangat sedikit. (Disproportionate Startified Random Sampling). Pengambilan sampel dengan mempertimbangkan tingkat pendidikan dan masa kerja. Teknik pengambilan sampel menggunakan rumus dari Taro Yamane (Riduwan, 2007:44) sebagai berikut:

$$
\begin{array}{ll} 
& n=\frac{N}{N d^{2}+1} \\
& \text { dimana: } \\
\mathrm{n} & =\text { Jumlah sampel } \\
\mathrm{N} & =\text { Jumlah Populasi } \\
\mathrm{d}^{2} \quad & =\text { tingkat presisi yang ditetapkan }(5 \%)
\end{array}
$$


Dengan rumus tersebut maka diperoleh jumlah sampel 282 orang responden.

Untuk uji coba instrumen dilakukan terhadap 30 pengajar yang dipilih secara acak yang bukan menjadi responden penelitian ini. Teknik pengumpulan data dilakukan dengan menggunakan instrumen penelitian berbentuk kuesioner. Namun sebelum intstrumen digunakan untuk penelitian Instrumen akan diuji coba terlebih dahulu pada pengajar yang bukan menjadi responden penelitian yang berjumlah 30 guru. Pengujian instrumen tersebut meliputi uji keabsahan (validity) dan uji keandalan (reliability). Dari hasil pengujian tersebut diperoleh butir-butir instrumen yang valid dan tidak valid. Adapun instrumen yang tidak valid dibuang.

Analisis data yang digunakan dalam penelitian ada dua bagian yaitu deskriptif dan analisis inferensial. Analisis data deskriptif yaitu statistik yang digunakan untuk menganalisis data dengan cara mendiskriptifkan atau menggambarkan data yang terkumpul sebagaimana apa adanya tanpa bermaksud membuat kesimpulan yang berlaku untuk umum atau generalisasi. Menurut Sugiono (2013:208) analisis deskriptif bertujuan untuk memperoleh gambaran karakteristik penyebaran skor setiap variabel penelitian dengan menghitung rata-rata, simpang baku, median, dan modus. Sedangkan statistik inferensial yaitu statistik yang menganalisa data, sampel dan hasilnya diberlakukan untuk populasi. Sebelum dilakukan pengujian hipotesis, terlebih dahulu dilakukan pengujian persyaratan analisis yanbg terdiri dari uji normalitas dan uji homogenitas.

Untuk efisiensi pengolahan data maka analisis deskriptif dan analisis inferensial baik untuk uji normalitas, menguji hipotesis pertama, menguji hipotesis kedua, dan menguji hipotesis ketiga menggunakan bantuan program komputer yaitu mengilah data dalam program SPSS versi 16.0. Pendiskripsian data dilakukan melalui penyajian data dengan menggunakan tabel distribusi frekuensi dan prosentase, sedangkan analisis statistik inferensial menggunakan : 1) Pengukuran data kuantitatif, pengukurannya dilakukan dengan menggunakan skala Likert dan 2) Analisis regresi linier sederhana

Setelah data terkumpul selanjutnya dianalisis dengan menggunakan metode statistik kuantitatif. Metode statistik yang digunakan adalah statistik deskriptif dan regresi ganda. Statistik deskriptif bertujuan untuk memperoleh gambaran karakteristik penyebaran skor setiap variabel yang diteliti dengan menghitung rata-rata, simpangan baku, median, modus serta visualisasi data berupa tabel dan grafik.

Analisis regresi linier sederhana untuk menguji hipotesis yaitu apakah ada atau tidak pengaruh yang signifikan secara simultan anatara kompensasi terhadap efektivitas pengelolaan sekolah untuk mendapatkan gambaran yang lebih luas dari penelitian ini dan terutama untuk melakukan usaha pengujian hipotesis dan sekaligus pemecahan terhadap masalah yang dihadapi, maka data yang diperoleh dianalisis dan dibahas secara kualitatif maupun kuantitatif yang saling menunjang dan tidak terpisah. Sebelum melakukan perhitungan regresi untuk mencari pengaruh antara variabel bebas dengan variabel terikat ada persyaratan uji yang harus dilakukan terlebih dahulu. Oleh karena itu peneliti melakukan beberapa yaitu uji Normalitas, Multikolinieritas, dan uji Heteroskedastisitas.

\section{HASIL \& PEMBAHASAN}

Diskripsi data hasil penelitian dimaksudkan untuk memberikan gambaran umum mengenai penyebaran data di lapangan. Data-data yang disajikan berasal dari data mentah yang telah diolah secara statistik diskriptif. Pada bagian ini diskripsi data disajikan dalam bentuk distribusi frekuensi, total skor, skor rata-rata, simpangan baku, modus, median, varians, skor minimum dan skor maksimum yang disertai dengan grafik histogram. Berdasarkan banyaknya variabel dan menunjuk kepada masalah penelitian, maka deskripsi data dapat dikelompokkan menjadi tiga bagian, yaitu meliputi data efektivitas pengelolaan sekolah (variabel Y) dan Kompensasi finansial dan non finansial (variabel X). Data disajikan didalam pembahasan adalah data yang diolah dari data mentah dengan menggunakan teknik statistik deskriptif terhadap 282 guru Sekolah Dasar di 3 kecamatan yaitu kecamatan Muara Jawa, Samboja dan Sanga-sanga. Berikut rangkuman hasil perhitungan secara statistik dari masing-masing variabel.

\section{Variabel Efektivitas pengelolaan sekolah (Y)}

Data hasil penelitian tentang variabel efektivitas pengelolaan sekolah dasar di Kabupaten Kutai Kartanegara yang dijaring melalui angket sebanyak 282 orang guru. Angket efektivitas pengelolaan sekolah mengukur kemampuan sekolah dalam 
melaksanakan tugas dan fungsinya dalam mencapai keberhasilan programsesuai dengan tujuan yang sudah ditentukan. Angket ini berupa pernyataan yang berjumlah 22 item dengan menggunakan skor penilaian skala Likert 1 sampai dengan 5.

\begin{tabular}{lrr}
\multicolumn{2}{l}{ Tabel 2 Data Statistik Diskriptif Efektivitas } \\
\hline \multicolumn{2}{c}{ Statistik Deskriftif } & Efektivitas \\
\hline $\mathrm{N}$ & Valid & 282 \\
\cline { 2 - 3 } & Missing & 0 \\
\hline Mean & 89.18 \\
\hline Median & 91.00 \\
\hline Mode & 95 \\
\hline Std. Deviation & 9.386 \\
\hline Variance & 88.097 \\
\hline Range & 53 \\
\hline Minimum & 55 \\
\hline Maximum & 108 \\
\hline Sum & 25148 \\
\hline
\end{tabular}

Pada Tabel 2 nampak bahwa ada 282 data yang berhasil terkumpul dan tidak ada data yang dihapus. Dari data tersebut nampak rentang skor atau jangkauan efektivitas pengelolaan SD di Kabupaten Kutai Kartanegara sebesar 53 yaitu skor terendah 55 dan skor tertinggi 108. Diperoleh ukuran pemusatan data yaitu mean (rata-rata) dengan skor sebesar 89,18 jika dibandingkan rerata skor ideal yaitu 55 maka rerata efektivitas pengelolaan sekolah masih di atas rerata skor ideal. Dengan demikian dapat mencerminkan bahwa efektivitas pengelolaan sekolah SD di Kabupaten Kutai Kartanegara dapat dikatakan baik. Dan nilai rerata/ mean sebesar 89,18
Adapun data diolah menggunakan program SPSS 16.0 for windows, maka diperoleh hasil analisis diskriptif seperti pada tabel 1.2 berikut ini: hampir sama dengan skor nilai median sebesar 91,00. Hal ini menunjukkan bahwa kebanyakan skor efektivitas pengelolaan sekolah SD di Kabupaten Kutai Kartanegara hampir seimbang antara skor yang berada di atas maupun di bawah skor rata-rata. Sedangkan nilai yang sering muncul (modus) adalah 91 hal ini berarti pada distribusi normal subyek banyak yang memilih atau memperoleh skor 91.

Selanjutnya untuk mengetahui kategori skor efektivitas pengelolaan SD di Kabupaten Kutai Kartanegara dapat dilihat pada sebaran data Efektivitas pengelolaan sekolah (Y) seperti pada Tabel 3 berikut ini.

Tabel 3 Distribusi Frekuensi Skor Efektivitas Pengelolaan Sekolah

\begin{tabular}{|c|c|c|c|c|}
\hline \multirow{2}{*}{ No } & \multirow{2}{*}{\multicolumn{2}{|c|}{ Kelas Interval }} & Frekuensi & Frekuensi \\
\hline & & & Absolut & Relatif (\%) \\
\hline 1 & 55 & -61 & 2 & 0.71 \\
\hline 2 & 61 & $\begin{array}{ll}-67 \\
\end{array}$ & 3 & 1.06 \\
\hline 3 & 67 & $\begin{array}{l}-73 \\
\end{array}$ & 16 & 5.67 \\
\hline 4 & 73 & -79 & 20 & 7.09 \\
\hline 5 & 79 & -85 & 45 & 15.96 \\
\hline 6 & 84 & -90 & 52 & 18.44 \\
\hline 7 & 90 & -96 & 85 & 30.14 \\
\hline 8 & 96 & -102 & 49 & 17.38 \\
\hline 9 & 102 & $\begin{array}{l}-108 \\
\end{array}$ & 10 & 3.55 \\
\hline & Jum & & 282 & 100 \\
\hline
\end{tabular}

Dari tabel distribusi di atas Guru SD di Kabupaten Kutai Kartanegara mempunyai efektivitas pengelolaan sekolah yang sedang. Untuk lebih memperjelas kecenderungan penyebaran distribusi skor variabel efektivitas pengelolaan sekolah secara grafis dapat dilihat pada gambar histogram di bawah ini: 


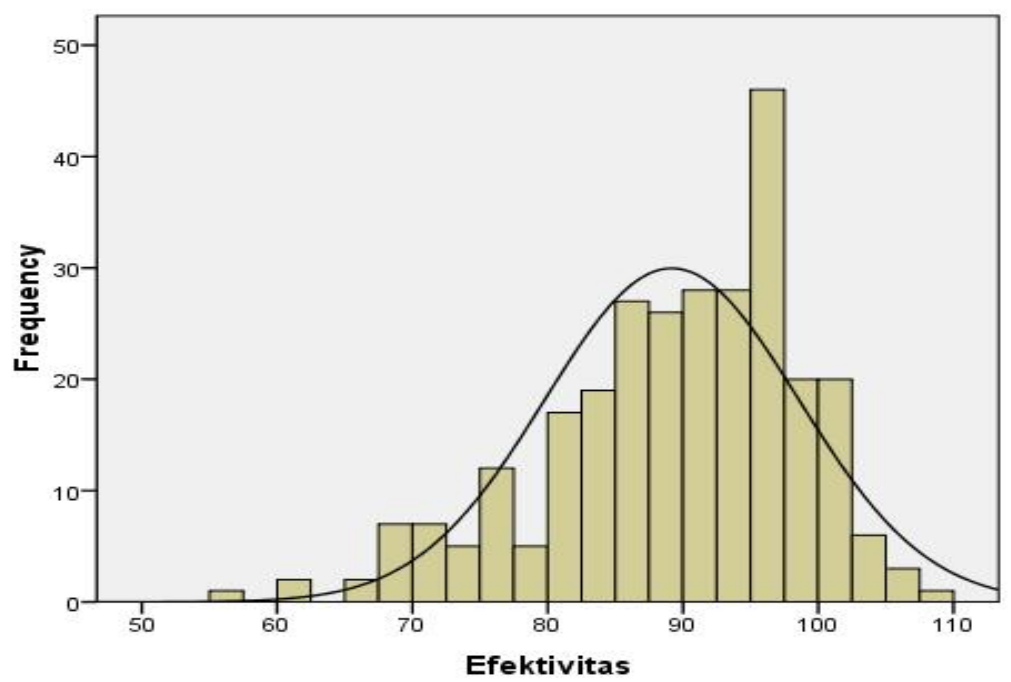

Gambar 1. Histogram Efektivitas

Pada Gambar 1 nampak bahwa distribusi skor membentuk kurva normal. Namun demikian terdapat sedikit kecondongan atau menjulur kesebelah kanan. Hal ini berarti bahwa skor nilai rata-rata lebih besar dari nilai tengah (median) yang berarti bahwa skor-skor variabel dapat dikatakan berdistribusi normal.

\section{Variabel Kompensasi finansial dan non finansial $(X)$}

Data hasil penelitian tentang variabel kompensasi finansial dan non finansial SDN di Kabupaten Kutai Kartanegara yang dijaring melalui angket sebanyak 282 orang guru. Angket kompensasi finansial dan non finansial yang mengungkap tentang balas jasa yang diberikan kepada pegawai sebagai sarana untuk mencapai tujuan organisasi, yang meliputi aspek ekstrinsik dan instrinsik. Angket ini berupa pernyataan yang berjumlah 20 item dengan menggunakan skor penilaian skala Likert 1 sampai dengan 5. Adapun data diolah menggunakan program SPSS 16.0 for windows, maka diperoleh hasil analisis diskriptif seperti pada tabel 4 berikut ini.

Tabel 4 Data Statistik Diskriptif Kompensasi

\begin{tabular}{|c|c|c|}
\hline & Statistik Deskriftif & Nilai \\
\hline \multirow[t]{2}{*}{$\mathrm{N}$} & Valid & 282 \\
\hline & Missing & 0 \\
\hline \multicolumn{2}{|c|}{ Mean } & 82.31 \\
\hline \multicolumn{2}{|c|}{ Median } & 84.00 \\
\hline \multicolumn{2}{|c|}{ Mode } & 80 \\
\hline \multicolumn{2}{|c|}{ Std. Deviation } & 10.135 \\
\hline \multicolumn{2}{|c|}{ Variance } & 102.727 \\
\hline \multicolumn{2}{|c|}{ Range } & 56 \\
\hline \multicolumn{2}{|c|}{ Minimum } & 44 \\
\hline \multicolumn{2}{|c|}{ Maximum } & 100 \\
\hline \multicolumn{2}{|c|}{ Sum } & 23211 \\
\hline
\end{tabular}

Pada Tabel di atas nampak bahwa ada 282 data yang berhasil terkumpul dan tidak ada data yang dihapus. Dari data tersebut nampak rentang skor atau jangkauan kompensasi finansial dan non finansial SDN di Kabupaten Kutai Kartanegara sebesar 56 yaitu skor terendah 44 dan skor tertinggi 100. Rerata skor sebesar 82,31 jika dibandingkan rerata skor ideal yaitu 50 maka rerata kompensasi masih di atas rerata skor ideal. Dengan demikian dapat mencerminkan bahwa kompensasi finansial dan non finansial SDN di Kabupaten Kutai Kartanegara dapat dikatakan baik. Dan nilai rerata/ mean sebesar 82,31 mendekati 
dengan skor nilai median sebesar 84,00 hal ini menunjukkan bahwa kebanyakan skor kompensasi finansial dan non finansial SDN di Kabupaten Kutai Kartanegara hampir seimbang antara skor yang berada di atas maupun di bawah skor rata-rata.
Selanjutnya untuk mengetahui kategori skor kompensasi finansial dan non finansial SDN di Kabupaten Kutai Kartanegara dapat dilihat pada sebaran data kompensasi finansial dan non finansial $(\mathrm{X})$ seperti pada Tabel 5 berikut ini.

Tabel 5 Distribusi Frekuensi Skor Kompensasi finansial dan non finansial

\begin{tabular}{|c|c|c|c|c|c|}
\hline \multirow{2}{*}{ No } & \multirow{2}{*}{\multicolumn{3}{|c|}{ Interval }} & Frekuensi & Frekuensi \\
\hline & & & & Absolut & Relatif (\%) \\
\hline 1 & 44 & - & 50 & 1 & 0.35 \\
\hline 2 & 50 & - & 56 & 5 & 1.77 \\
\hline 3 & 56 & - & 63 & 5 & 1.77 \\
\hline 4 & 63 & - & 69 & 16 & 5.67 \\
\hline 5 & 69 & - & 75 & 35 & 12.41 \\
\hline 6 & 75 & - & 81 & 56 & 19.86 \\
\hline 7 & 81 & - & 88 & 73 & 25.89 \\
\hline 8 & 88 & - & 94 & 52 & 18.44 \\
\hline 9 & 94 & - & 100 & 39 & 13.83 \\
\hline & Jur & & & 282 & 100 \\
\hline
\end{tabular}

Dari tabel distribusi di atas SDN di Kabupaten Kutai Kartanegara mempunyai kompensasi finansial dan non finansial yang sedang. Untuk lebih memperjelas kecenderungan penyebaran distribusi skor variabel kompensasi finansial dan non finansial secara grafis dapat dilihat pada gambar histogram di bawah ini.

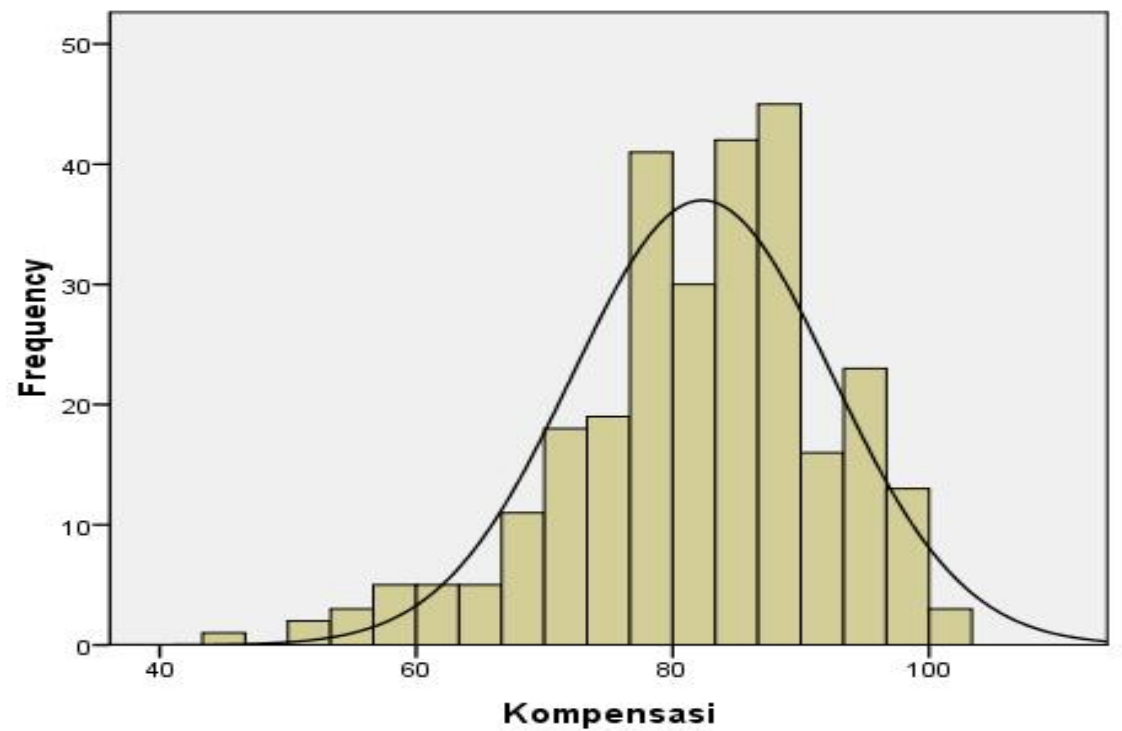

Gambar 2 Histogram Kompensasi

Pada gambar 2 nampak bahwa distribusi skor membentuk kurva normal. Namun demikian terdapat sedikit kecondongan atau menjulur kesebelah kanan. Hal ini berarti bahwa skor nilai rata-rata 82,31 mendekati nilai tengah (median) 84,00 yang berarti bahwa skor-skor variabel dapat dikatakan berdistribusi normal.

\section{Hasil Perhitungan Uji Hipotesis}

Hipotesis yang diuji adalah:

$\mathrm{H}_{\mathrm{o}}: \rho_{\mathrm{y} 1}=0$

$\mathrm{H}_{1}: \rho_{\mathrm{yl}}>0$

Hipotesis yang dikemukakan untuk hipotesis alternatif $\left(\mathrm{H}_{1}\right)$ adalah "terdapat pengaruh yang positif dan signifikan antara kompensasi finansial dan non finansial dengan efektivitas pengelolaan SDN di Kabupaten Kutai Kartanegara”. Sedangkan untuk 
hipotesis nol $\left(\mathrm{H}_{0}\right)$ dirumuskan, ”tidak terdapat pengaruh yang positif dan signifikan antara kompensasi finansial dan non finansial dengan efektivitas pengelolaan SDN di Kabupaten Kutai Kartanegara”. Untuk keperluan pengujian digunakan analisis regresi sederhana.

Hasil perhitungan analisis regresi uji signifikansi persamaan garis regresi sederhana dan linieritas antara variabel kompensasi finansial dan non finansial (X) dengan efektivitas pengelolaan sekolah (Y) menghasilkan arah regresi (b) sebesar 0,545 dan konstanta (a) sebesar 44,298. Dengan demikian bentuk persamaan linier kedua variabel tersebut dapat digambarkan sebagai berikut $\hat{Y}=44,298+0,545$ X.

Selanjutnya untuk mengetahui derajat keberartian persamaan regresi dilakukan dengan uji F. Persyaratan hipotesis apabila Sig $<\alpha=0,05$. Berdasarkan hasil perhitungan uji signifikansi regresi seperti tampak pada tabel 4.18 diperoleh nilai $\mathrm{Sig}=0,000$. Apabila nilai sig di bandingkan dengan nilai $\alpha$, maka 0,000 $<0,05$. Hal ini menunjukkan bahwa pengaruh antara variabel variabel kompensasi finansial dan non finansial (X) dengan variabel efektivitas pengelolaan sekolah (Y) adalah positif dan signifikan. Selengkapnya hasil perhitungan uji signifikansi dan nilai koefisien regreasi antara variabel variabel kompensasi finansial dan non finansial (X) dengan variabel efektivitas pengelolaan sekolah (Y) dapat dilihat pada tabel di bawah ini

\begin{tabular}{|c|c|c|c|c|c|c|}
\hline \multicolumn{2}{|c|}{ Model } & \multirow{2}{*}{$\begin{array}{r}\text { Sum of Squares } \\
8582.167\end{array}$} & \multirow{2}{*}{$\frac{\text { Df }}{1}$} & \multirow{2}{*}{$\begin{array}{r}\text { Mean Square } \\
8582.167\end{array}$} & \multirow{2}{*}{$\frac{F}{148.582}$} & \multirow{2}{*}{$\begin{array}{l}\text { Sig. } \\
.000^{\mathrm{a}}\end{array}$} \\
\hline 1 & Regression & & & & & \\
\hline & Residual & 16172.968 & 280 & 57.761 & & \\
\hline & Total & 24755.135 & 281 & & & \\
\hline
\end{tabular}

Berdasarkan hasil uji F pada tabel di atas diperoleh $\mathrm{F}_{\text {hitung }} 148,582>3,875 \mathrm{~F}_{\text {tabel }}$ dengan sig $=0,000<5 \%$ ini berarti model regresi linier dapat digunakan untuk memprediksi pengaruh kompensasi finansial dan non finansial terhadap efektivitas pengelolaan sekolah. Sedangkan untuk menguji signifikansi koefisien parameter regresi antara variabel kompensasi finansial dan non finansial $\left(\mathrm{X}_{2}\right)$ dengan variabel efektivitas pengelolaan sekolah (Y) hipotesis yang digunakan $\mathrm{H}_{\mathrm{o}}$ yang menyebutkan bahwa variabel kompensasi finansial dan non finansial tidak mempengaruhi variabel efektivitas pengelolaan sekolah dan hipotesis alternatif $\left(\mathrm{H}_{1}\right)$ menyebutkan bahwa variabel kompensasi finansial dan non finansial (X) mempengaruhi variabel efektivitas pengelolaan sekolah (Y) dengan melakukan pengujian hipotesis secara parsial (uji t). Hasil perhitungan dapat dilihat pada tabel 7:

Tabel 7 Hasil Uji t Persamaan Regresi X Terhadap Y

Coefficients $^{\mathrm{a}}$

\begin{tabular}{|c|c|c|c|c|c|}
\hline \multirow[b]{2}{*}{ Model } & \multicolumn{2}{|c|}{$\begin{array}{l}\text { Unstandardized } \\
\text { Coefficients }\end{array}$} & \multirow{2}{*}{$\begin{array}{c}\text { Standardized } \\
\text { Coefficients } \\
\text { Beta } \\
\end{array}$} & \multirow[b]{2}{*}{$\mathrm{T}$} & \multirow[b]{2}{*}{ Sig. } \\
\hline & B & Std. Error & & & \\
\hline 1 (Constant) & 44.298 & 3.710 & & 11.942 & .000 \\
\hline Kompensasi & .545 & .045 & .589 & 12.189 & .000 \\
\hline
\end{tabular}

Berdasarkan hasil perhitungan diperoleh nilai $\mathrm{t}_{\text {hitung }}=12.189>1,969 \mathrm{t}_{\text {tabel }}$ dan dengan $\operatorname{sig}=0,000<5 \%$ maka $\mathrm{H}_{0}$ ditolak. Ini berarti variabel kompensasi finansial dan non finansial secara statistik berpengaruh signifikan terhadap variabel dependen efektivitas pengelolaan sekolah. Maka secara parsial variabel kompensasi finansial dan non finansial (X) mempengaruhi variabel efektivitas pengelolaan sekolah (Y). Dengan demikian dapat disimpulkan bahwa persamaan regresi $. \hat{\mathrm{Y}}=44,298+0,545 \mathrm{X}$ dikatakan pengaruhnya signifikan. Persamaan regresi tersebut dapat diinterpretasikan jika kompensasi finansial dan non finansial $=0$ maka efektivitas pengelolaan sekolah sebesar 44,298 dan jika variabel kompensasi finansial dan non finansial mangalami kenaikan satu poin maka akan menyebabkan kenaikan pada variabel efektivitas pengelolaan sekolah sebesar 0,545. 
Gambaran persamaan regresi linier variabel kompensasi finansial dan non finansial (X) mempengaruhi variabel efektivitas pengelolaan sekolah (Y) dapat dilihat pada gambar 3 di bawah ini:

Scatterplot

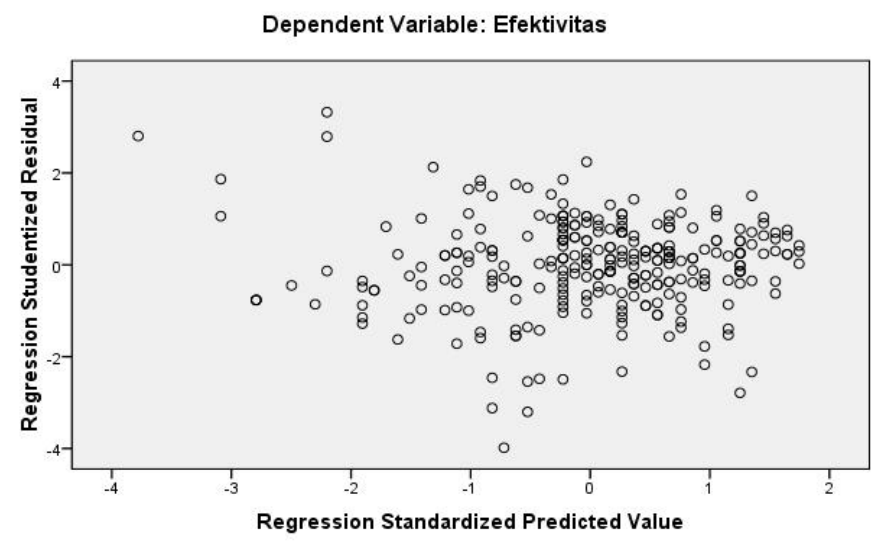

Gambar 3. Grafik Regresi Linier

Uji determinasi digunakan untuk melihat seberapa besar pengaruh variabel independen terhadap variabel dependen. Nilai koefisien determinasi antara kompensasi finansial dan non finansial dengan variabel efektivitas pengelolaan sekolah adalah $\mathrm{r}_{\mathrm{yx} 1}{ }^{2}=0,347$, hal ini berarti bahwa $34,7 \%$ varians efektivitas pengelolaan sekolah dapat dipengaruhi oleh kompensasi finansial dan non finansial dan sisanya dipengaruhi oleh variabel lain yang tidak berhasil diteliti.

\section{Pembahasan Hasil Penelitian}

Berdasarkan hasil analisis data di atas, maka diperoleh hasil penelitian yang telah diuji berdasarkan hipotesis yang ada. Dari kelima variabel yang diuji memiliki pengaruh yang positif dan signifikan. Berikut ini pembahasan pengaruh masing-masing variabel bebas terhadap variabel terikat.

Hasil Uji regresi linier antara kompensasi finansial dan non finansial dengan efektivitas pengelolaan sekolah menunjukkan bahwa memiliki pengaruh yang signifikan dan positif maka semakin baik kompensasi finansial dan non finansial semakin tinggi pula efektivitas pengelolaan sekolah tersebut. McKenna (2006:608) mengemukakan bahwa kompensasi mencakup berbagai aktivitas organisasi yang ditujukan bagi alokasi kompensasi dan tunjangan bagi pegawai sebagai imbalan atas usaha dan sumbangan yang dibuat untuk mencapai tujuan organisasi. Berdasarkan pendapat tersebut memperjelas bahwa kompensasi diberikan dengan tujuan pencapaian tujuan organisasi yang sudah ditetapkan.
Kompensasi memiliki sejumlah fungsi. Pertama, fungsi motivasi. Imbalan diberikan kepada pegawai agar memotivasi kinerjanya dan mendorong kesetiaan dan rasa memiliki.(Luthans, 2008:93) Kedua, fungsi pengawasan. Semua imbalan memiliki potensi untuk mengontrol. Imbalan mengontrol perilaku ketika ditujukan pada individu yang menyelesaikan tugas tertentu atau bekerja di tingkat tertentu. Ketika orang melihat imbalan sebagai mengontrol perilakunya (yakin bertindak dengan cara untuk memeroleh imbalan), orang tersebut menganggap tindakannya berasal dari faktor-faktor di luar dirinya (imbalan) dan yang bersangkutan kehilangan rasa penentuan diri. Ketika kemungkinan imbalan tidak lagi berlaku, tidak ada yang mendorong dirinya untuk menggarap aktivitas, jadi kepentingannya akan berkurang.( Schunk,dkk,2008,261)

Ketiga, fungsi informasi. Imbalan juga menyampaikan informasi tentang keahlian atau kemampuan seseorang ketika dihubungkan dengan kinerja atau kemajuan, seperti ketika pimpinan memuji pegawai untuk mempelajari keahlian baru atau memeroleh pengetahuan baru, pengawas memberi pegawai kenaikan upah untuk bekerja di atas standar, dan orangtua membelikan anaknya mainan untuk membuat ruangan tetap bersih. Ketika orang memeroleh informasi kerja dari imbalan, orang tersebut merasakan efikasi dan mengalami penentuan diri. Motivasi intrinsik diperkuat bahkan ketika kemungkinan imbalan terhapus karena orang menempatkan wadah kausalitas perilaku dalam dirinya (keinginan untuk belajar). 
Fungsi-fungsi itu berlangsung untuk mencapai tujuan kompensasi yang menurut Moorhead \& Griffin (2006:608) adalah: menarik, memertahankan dan memotivasi pegawai yang berkualitas. Selain itu, tujuan kompensasi adalah menciptakan sistem imbalan yang sesuai bagi pegawai dan majikan. Hasil yang diinginkan adalah seorang pegawai yang terikat pada pekerjaannya dan termotivasi untuk melakukan pekerjaan yang baik bagi pegawai. (Ivancevich,dkk,207:295) Dengan kata lain, sasaran utama program imbalan adalah menarik orang-orang berkualitas untuk memasuki organisasi, menjaga pegawai agar tetap bekerja, dan mendorong pegawai untuk mencapai tingkat kinerja yang tinggi yang akan berimbas pada pencapain tujuan organisasi dalam hal ini efektivitas pengelolaan sekolah.

Namun dalam pemberian kompensasi harus memperhatikan beberapa hal penting sehingga pemberian kompensasi tepat sasaran. Patton menyebutkan 7 kebijakan dalam pemberian kompensasi yakni (1) memadai: tingkat pemerintahan, serikat buruh dan manajemen minimal hendaknya dipenuhi; (2) sepadan: setiap orang hendaknya dibayar layak, sesuai dengan usaha, kemampuan dan pelatihannya; (3) seimbang: upah, keuntungan dan imbalan lain hendaknya memberikan suatu paket imbalan yang layak; (4) efektif biaya: upah jangan berlebihan, memertimbangkan apa yang harus dibayar oleh organisasi; (5) terjamin: upah hendaknya cukup untuk membantu pegawai merasa terjamin dan membantunya dalam memenuhi kebutuhan dasarnya; (6) memberikan insentif: upah hendaknya memotivasi pekerjaan yang efektif dan produktif; dan (7) diterima pegawai: pegawai hendaknya memahami sistem upah dan merasakannya sebagai sistem yang layak bagi perusahaan atau dirinya sendiri. (Ivancevich,dkk,207:295)

Berdasarkan pembahasan di atas menunjukkan bahwa kompensasi finansial dan non finansial memiliki pengaruh yang signifikan dan positif terhadap efektivitas pengelolaan sekolah. Dengan demikian peneliti berpendapat bahwa kompensasi finansial dan non finansial tidak dapat diabaikan dalam meningkatkan efektivitas pengelolaan sekolah.

\section{KESIMPULAN \& SARAN}

Dari penelitian ini penulis dapat menyimpulkan bahwa terdapat pengaruh yang signifikan dan positif antara kompensasi finansial dan non finansial terhadap efektivitas pengelolaan sekolah dengan hasil uji $\mathrm{F}=$ 148.582 dan uji $\mathrm{t}=12.189$ dengan nilai signifikansi 0,000 . Kontribusi kompensasi finansial dan non finansial terhadap variabel efektivitas pengelolaan sekolah adalah 0,347 yang dapat diinterpretasikan bahwa sebesar $34,7 \%$ varian efektivitas pengelolaan sekolah dapat dipengaruhi oleh variabel kompensasi finansial dan non finansial dan sisanya dipengaruhi variabel lain yang tidak diteliti dalam penelitian ini.

Saran yang dapat peneliti ajukan dalam penelitian ini adalah dari hasil analisis yang dilakukan oleh peneliti bahwa kompensasi finansial dan non finansial mempunyai pengaruh signifikan terhadap efektivitas pengelolaan sekolah. Oleh karena itu resiko adanya penurunan efektivitas pengelolaan sekolah yang disebabkan oleh faktor kompensasi finansial dan non finansial harus ditanggulangi. Dengan upaya-upaya yang serius, maka diharapkan untuk masa yang akan datang peranan kompensasi finansial dan non finansial akan tetap memberikan kontribusi dalam meningkatkan efektivitas pengelolaan sekolah.

Bagi para peneliti yang akan meneliti faktor yang berhubungan dengan efektivitas pengelolaan sekolah, aspek-aspek lain yang selama ini belum diteliti perlu diteliti pengaruhnya terhadap efektivitas pengelolaan sekolah. Aspek-aspek tersebut misalnya kesejahteraan, budaya kerja, hubungan antara personal, kreativitas, supervisi, dan lain-lain.

\section{DAFTAR PUSTAKA}

Adeyemi, T.O.. "The effective management of primary schools in Ekiti State, Nigeria: An analitytuical assessment". Educational Research and Review. Vol. $4 \quad$ (2). Pp. $\quad$ 048-056. 2009. http://www.academicjournals.org/ERR (diakses 10 Nopember 2016)

Agung, Kurniawan. Transformasi Pelayanan Publik. Yogyakarta: Pembaharuan. 2005 Atmodiwirio, Soebagio. Manajemen Pelatihan. Jakarta: Ardadizya Jaya. 2002

Beteille, Tara. dkk. "Effective schools: Managing the recruitment, development, and retention of hight-quality teacher". National Center fo Analysis of Longitudinal Data in Educational Research. 2009. http://www.caldercenter.org diakses 10 Nopember 2016 
Campbell. Riset dalam Efektivitas Organisasi, Terjemahan Sahat Simamora. Jakarta: Erlangga, 1989

Chairunnisa, Connie. (2009), dengan judul : "Pengaruh kepemimpinan, sistem dan struktur organisasi, serta lingkungan fisik terhadap keefektifan organisasi (Studi Klausal pada SMP-SMP Negeri se Provinsi DKI Jakarta)". Disertasi. Universitas Negeri Jakarta

Daft, Richard L. Manajemen Sumber Daya Manusia. Jakarta: Penerbit. Erlangga, 2003

Gibson, James L.. dkk. Organization Behavior, Stucture, Processes. New York: McGraw-Hill, 2012

Hersev, Paul, Et. Al, Managemen Of Organisation Behavior \& Utilizing Human Recaurses. Third Editsun, 1997). by Prentice-Hall, Inch, Englewood lifts. New Jersey 07832

Hersey, Paull and Ken Blanchard, Majemen Perilaku Organisasi : Pendayagunaan Sumber Daya Manusia, terj. Jakarta: Erlangga, 1982

Ismaya, Bambang. Pengelolaan Pendidikan. Bandung : Refika Aditama, 2015

Kameron, Kim. "A study of organizational effectiveness and its predictors". Management Science Journal. Vol. 32. No. 1 pp. 087-112. 1989. https://www.researchgate.net. diakses 12 Nopember 2016

Lubis, Hari. S.B. dan Martani Husaini. Teori Organisasi (Suatu Pendekatan Makro), (Pusat Antar Universitas Ilmu-ilmu Sosial) Jakarta: Universitas Indonesia, 1987

Luthans, Fred. Organizational Behavior, (Interpreting VA Yuwono, et al), Edition Indonesian, Yogyakarta: ANDI, 2008

Morisson, Keith. Defining Efective Schools. Published on the companion web resource for A Guide to Teaching Practice: RoutledgeFalmer. 2004

Mustiningsih. 2015. Masalah Implementasi Manajemen Berbasis Sekolah Di Sekolah Dasar. http://ap.fip.um.ac.id/ Jurnal Manajemen Pendidikan Universitas Malang Vol. 24, No. 6, September 2015: 498-505. Diakses 10 Nopember 2016

Peraturan Pemerintah Nomor 32 Tahun 2013 Tentang Perubahan Atas Peraturan Pemerintah Nomor 19 Tahun 2005 Pasal 19 Ayat 1
Peraturan Menteri Pendidikan Nasional Nomor 19 tahun 2007 tentang Standar Pengelolaan Pendidikan oleh Satuan Pendidikan Dasar dan Menengah

Peraturan Pemerintah Republik Indonesia Nomor 19 tahun 2005 tentang Standar Nasional Pendidikan

Riduwan dan Engkos Achmad Kuncoro. Cara Menggunakan Dan Memakai Analisis Jalur. Bandung: Alfabeta, 2007

Schunk, DH, Pintrich, PR, \& Meece, JL. Motivation in Education: Theory, Research, and Applications Third Edition. New Jersey: Pearson Education, 2008

Sopiah. Perilaku Organsisasional. Yogyakarta: Andi Offset, 2008

Sugiyono. Metode Penelitian Pendidikan: Pendekatan Kuantitatif, Kualitatif, dan $R \& D$. Bandung: Penerbit Alfaberta: 2013

Steers, M. Richard. Efektivitas Organisasi. Jakarta: Erlangga, 1985

Tulus, Moh. Agus. Human Resource Management: A Guide Students, Jakarta: PT. Gramedia Pustaka Utama, 1995

Undang-Undang Republik Indonesia Nomor 20 Tahun 2003 tentang Sistem Pendidikan Nasional

Undang-Undang Republik Indonesia Nomor 23 tahun 2014 tentang Pemerintahan Daerah

Usman, Husaini. Manajemen Teori. Praktik dan Riset Pendidikan Edisi 4. Jakarta: Bumi Aksara, 2014 